Hal. 12 - 27

\title{
ANALISIS FAKTOR-FAKTOR YANG MEMENGARUHI ABNORMAL RETURN SAHAM PADA PERUSAHAAN PERBANKAN DAN ASURANSI YANG TERDAFTAR DI BURSA EFEK INDONESIA
}

\author{
Sidiq Jati Permana \\ Program Magister Manajemen, Fakultas Ekonomi, Universitas Jember \\ ganteng.permana123@gmail.com
}

\begin{abstract}
This research aims to analyzes the effect of profitability (NPM and ROE) and leverage (DER and DR) partially to stock abnormal returns at the Banking and Insurance Companies Listed Indonesia Stock Exchange, also to analyze the different effect of profitability (NPM and ROE) and leverage (DER and DR) on stock abnormal returns at the Banking and Insurance Companies Listed Indonesia Stock Exchange. Data used in this research are secondary data collected from ICMD and Annual Report of Companies in Indonesia Stock Exchange at 2010 - 2014, and www.yahoofinance.com. The populations in this research are the Banking and Insurance Companies Listed in Indonesia Stock Exchange. Sampling method is purposive sampling. The model of analysis used in this research is multiple linier regressions. Results of this research show that NPM have positively and significant effet on stock abnormal return at the Banking and Insurance Companies Listed Indonesia Stock Exchange. ROE have positively and significant effect on stock abnormal returns. DER has negatively but not significant effect on stock abnormal returns at the Banking and Insurance Companies Listed Indonesia Stock Exchange. DR has positively but not significant effect on stock abnormal returns at the Banking Companies Listed Indonesia Stock Exchange. While for the insurance companies, DR has negative effect but not significant on stock abnormal returns. There are differences in the effect of profitability (NPM and ROE) and leverage (DER and DR) to the stock abnormal returns on the Banking Companies Listed Indonesia Stock Exchange.
\end{abstract}

Keywords: profitability, leverage, Net Profit Margin/NPM, Return on Equity/ROE, Debt to Equity Ratio/DER, Debt Ratio/DR, and abnormal return

\begin{abstract}
Abstrak: Penelitian ini menguji pengaruh profitabilitas (NPM dan ROE) dan leverage (DER dan DR) secara parsial terhadap abnormal return saham pada perusahaan Perbankan dan Asuransi di BEI, serta menguji perbedaan pengaruh profitabilitas (NPM dan ROE) dan leverage (DER dan DER) terhadap abnormal return saham pada perusahaan Perbankan dan Asuransi di BEl. Data yang digunakan dalam penelitian ini adalah data sekunder yang diambil dari ICMD dan Laporan Keuangan tahunan perusahaan di BEI pada tahun 2010 - 2014, serta www.yahoofinance.com. Populasi dalam penelitian ini adalah perusahaan Perbankan dan Asuransi yang go public di BEI. Sampel dalam penelitian ini menggunakan metode purposive sampling. Model analisis yang digunakan dalam penelitian ini adalah analisis regresi linier berganda. Hasil penelitian menunjukkan bahwa KNPM berpengaruh positif namun tidak signifikan terhadap abnormal return saham. ROE berpengaruh positif dan signifikan terhadap abnormal return saham pada perusahaan Perbankan dan Asuransi di BEI. DER berpengaruh negatif namun tidak signifikan terhadap abnormal return saham pada perusahaan Perbankan dan Asuransi di BEI. DR berpengaruh positif namun tidak signifikan terhadap abnormal return saham pada perusahaan Perbankan di BEI. Sedangkan pada perusahaan Asuransi di BEI, DR berpengaruh negatif namun tidak signifikan terhadap abnormal return saham. Dan, ada perbedaan pengaruh profitabilitas (NPM dan ROE) dan leverage (DER dan DR) terhadap abnormal return saham pada perusahaan Perbankan dan Asuransi di BEl.
\end{abstract}

Kata Kunci: profitabilitas, leverage, Net Profit Margin/NPM, Return on Equity/ROE, Debt to Equity Ratio/DER, Debt Ratio/DR, dan abnormal return 


\section{Pendahuluan}

Pasar modal merupakan salah satu alternatif yang dapat dimanfaatkan untuk memperbaiki struktur modal perusahaan (menghindarkan perusahaan dari debt to equity ratio yang tinggi) dan meningkatkan nilai perusahaan terutama bagi perusahaan yang bergerak di sektor perbankan dan asuransi yang go public. Bagi emiten, pasar modal merupakan lahan untuk mendapatkan uang yang digunakan untuk modal investasi. Sementara bagi investor, pasar modal merupakan lahan untuk menginvestasikan uangnya. Dengan kata lain pasar modal merupakan jembatan yang menghubungkan antara penyedia dana yang disebut investor dengan pengelola dana yang disebut emiten.

Saham sebagai salah satu alternatif media investasi pada pasar modal memiliki tingkat risiko jauh lebih tinggi dibandingkan dengan tabungan atau deposito yang saat ini dijamin oleh pemerintah. Namun, saham juga memiliki potensi tingkat keuntungan yang lebih besar. Hal ini disebabkan pendapatan yang diharapkan tidak pasti, pendapatan saham yang diterima terdiri atas dividen (bagian laba yang dibagikan) dan capital gain (kenaikan harga saham). Stockholders mengharapkan pendapatan saham tersebut harus lebih besar atau minimal sama dengan pendapatan yang diharapkan (expected return). Seorang investor baik dalam skala besar maupun kecil akan memperhitungkan pendapatan yang diharapkan (expected return), tingkat risiko (risk) dan konsekuensinya juga memperhitungkan capital gain dan capital loss.

Dalam mengambil keputusan investasi saham, seorang investor yang rasional didahului dengan proses analisis investasi yang salah satunya adalah analisis laporan keuangan perusahaan yang mensyaratkan saham melalui pasar modal. Analisis terhadap laporan keuangan tersebut akan mengetahui gambaran kinerja perusahaan dalam menjalankan kegiatan usahanya. Laporan keuangan yang dikeluarkan oleh emiten merupakan salah satu pedoman yang penting bagi investor untuk melihat kondisi emiten tersebut. Oleh karena itu, perusahaan-perusahaan yang telah tercatat di Bursa Efek, yang juga berarti telah menjual saham-sahamnya kepada publik, wajib mengumumkan laporan keuangannya secara periodik.

Berdasarkan laporan keuangan tersebut, dapat diketahui kemampuan perusahaan dalam mendayagunakan aktivitas usahanya secara efisien dan efektif (dalam hal ini penggunaan modal) serta untuk mendapatkan gambaran yang lebih jelas terhadap kemampuan perusahaan tersebut untuk tumbuh dan berkembang dimasa yang akan datang. Analisis rasio keuangan adalah salah satu alat untuk membantu 
dalam menganalisis laporan keuangan yang dapat digunakan sebagai indikator kinerja keuangan perusahaan yang merupakan sebagian dari faktor-faktor fundamental yang diperkirakan akan memengaruhi harga saham.

Harga saham bisa dikatakan sebagai indikator pengelolaan perusahaan, sehingga kekuatan pasar ditunjukkan dengan besar kecilnya transaksi perdagangan saham di pasar modal. Terjadinya transaksi didasarkan pada pengamatan para investor terhadap prestasi perusahaan dalam menghasilkan keuntungan. Pada prinsipnya semakin baik kinerja perusahaan dalam menghasilkan keuntungan, akan meningkatkan permintaan saham perusahaan yang bersangkutan, sehingga terjadi kenaikan harga pasar saham. Jika keadaan yang terjadi adalah keadaan yang sebaliknya, maka harga pasar saham perusahaan yang bersangkutan akan mengalami penurunan. Harga saham merupakan ukuran indeks kinerja perusahaan, yaitu bagaimana manajemen telah berhasil mengelola perusahaan atas nama pemegang saham. Oleh karena itu, kegiatan operasional perusahaan harus dilakukan secara efektif dan efisien untuk mencapai tujuan perusahaan. Persoalan yang timbul adalah sejauhmana perusahaan mampu memengaruhi persepsi investor di pasar modal dan faktor apa saja yang dapat dijadikan sebagai indikator, dimana perusahaan masih mampu untuk mengendalikannya. Hal ini berarti manajemen perusahaan harus diusahakan agar mencapai kinerja yang diinginkan dan memiliki kondisi fundamental perusahaan yang bagus.

Menurut Syamsudin (2004), salah satu ukuran untuk mengetahui penghasilan yang tersedia sebagai pemilik perusahaan atas modal yang diinvestasikan di dalam perusahaan diukur dengan analisis ROE (Returm on Equity) dan untuk mengetahui seberapa besar penghasilan atas jumlah keseluruhan aktiva yang tersedia di dalam perusahaan diukur dengan analisis ROA (Return on Assets). Kedua aspek ini merupakan bagian dari analisis laporan keuangan yang dikenal sebagai analisis fundamental. Dalam kaitannya dengan analisis laporan keuangan, investor harus memperhitungkan seberapa besar profit atau laba yang diperoleh perusahaan serta seberapa besar pinjaman atau hutang perusahaan. Kondisi ini penting khususnya bagi perusahaan yang bergerak di sektor perbankan dan asuransi, karena komponen kewajiban dan modal perusahaan ini didominasi oleh sumber dana hutang. Komponen hutang dalam neraca sering disebut sebagai aspek leverage keuangan (financial leverage) 
Untuk mengetahui financial leverage dari suatu perusahaan dapat diukur dengan analisis DER (Debt Equity Ratio) yang mengukur seberapa besar pinjaman jangka panjang perusahaan atas modal yang diinvestasikan, dan analisa DR (Debt Ratio) yaitu untuk mengukur seberapa besar pinjaman yang dimiliki perusahaan atas jumlah keseluruhan aktiva yang tersedia di dalam perusahaan. Selain melakukan analisis, investor juga harus memperhatikan tingkat risiko karena apabila investor melakukan kesalahan dalam analisis dan tidak memperhatikan risiko yang akan dihadapi maka keuntungan yang akan diharapkan dari investasi yang dilakukan akan mengalami kerugian.

Penilaian saham secara akurat bisa meminimalkan risiko sekaligus membantu investor mendapatkan keuntungan wajar mengingat investasi saham di pasar modal merupakan jenis investasi yang cukup berisiko tinggi meskipun menjanjikan keuntungan relatif besar. Teknik yang benar dalam analisis akan mengurangi risiko bagi investor dalam berinvestasi. Tujuan investor melakukan analisis terhadap sahamsaham adalah untuk mendapatkan keuntungan (rate of return) yang optimal untuk level risiko (risk) tertentu.

Penelitian tentang pengaruh profitabiltas dan leverage terhadap harga saham antara lain dilakukan oleh Sulaiman (1995) dalam Natarsyah (2000) yang meneliti perusahaan industri barang konsumsi yang listed di Bursa Efek Jakarta (BEJ) untuk menguji pengaruh faktor fundamental yang terdiri atas ROA, DPR, leverage keuangan, tingkat pertumbuhan, likuiditas, struktur modal, dan tingkat bunga deposito terhadap harga saham. Hasil penelitian tersebut menyatakan bahwa ROA, tingkat pertumbuhan, likuiditas, struktur modal, dan tingkat bunga deposito berpengaruh signifikan terhadap harga saham. Sedangkan variabel DPR dan leverage keuangan tidak berpengaruh signifikan terhadap harga saham.

Purnomo (1998) menguji kemampuan kinerja keuangan dalam menjelaskan variasi harga saham pada perusahaan manufaktur yang listed di Bursa Efek Jakarta (BEJ). EPS (eaming per share), PER (price to eaming ratio), DER (debt to equity ratio), ROE (return on equity) dan DPS (dividend per share) diregresikan terhadap harga saham. Hasil penelitian menunjukkan bahwa EPS (earning per share), PER (price earning ratio), DER (debt to equity ratio), ROE (return on equity) dan DPS (divident per share) secara parsial berpengaruh signifikan dalam menjelaskan variasi harga saham.

Anastasia et al. (2003) meneliti tentang faktor fundamental dan risiko sistematik terhadap harga saham properti di BEI. Faktor fundamental yang diteliti terdiri dari 
Return on Total Asset (ROA), Return on Equity (ROE), Book Value (BV), Debt Equity Ratio (DER), dan Required Rate of Return (r). Hasilnya menyatakan bahwa secara parsial hanya book value berpengaruh signifikan terhadap harga saham artinya investor bersedia membayar harga saham lebih tinggi apabila ada jaminan keamanan atau nilai klaim atas aset bersih perusahaan yang semakin tinggi. Sedangkan Return on Total Asset (ROA), Return on Equity(ROE), Debt Equity Ratio(DER), dan Required Rate of Return ( $r$ ) tidak berpengaruh signifikan terhadap harga saham.

Angkasari (2004) menguji pengaruh faktor fundamental (PER, BVPS, FL, dan EPS) terhadap harga saham pada perusahaan manufaktur yang listed di Bursa Efek Jakarta (BEJ). Hasil penelitian menyatakan bahwa EPS dan PER berpengaruh signifikan terhadap harga saham. Sedangkan variabel BVPS dan FL tidak berpengaruh signifikan terhadap harga saham. Sementara Ardianto (2007) menemukan Return on Equity (ROE), Return on Asset(ROA), Debt to Equity Ratio (DER), dan Debt Ratio(DR) berpengaruh signifikan terhadap harga saham.

Temuan dalam penelitan sebelumnya menunjukkan hasil yang berbeda-beda, sehingga masih diperlukan penelitian lanjutan untuk memperoleh gambaran yang lebih baik mengenai faktor-faktor yang memengaruhi harga saham. Penelitian ini memiliki persamaan dengan penelitian terdahulu yaitu sama-sama menganalisis pengaruh rasio profitabilitas dan leverage terhadap harga saham. Adapun perbedaannya terletak pada obyek penelitian dan periode tahun yang akan dianalisis. Pada penelitian ini obyek yang digunakan adalah perusahaan perbankan dan asuransi di BEI pada periode tahun 2010 sampai dengan 2014. Kedua objek ini dipilih karena sama-sama bergerak di sektor keuangan.

Berdasarkan uraian di atas, maka rumusan masalah dalam penelitian ini adalah apakah profitabilitas (NPM dan ROE) dan leverage (DER dan DR) berpengaruh terhadap abnormal return saham pada perusahaan Perbankan dan Asuransi di BEl? Apakah ada perbedaan pengaruh profitabilitas (NPM dan ROE) dan leverage (DER dan DR) terhadap abnormal return saham pada perusahaan Perbankan dan Asuransi di BEI?

\section{Metodologi}

\section{$\underline{\text { Rancangan Penelitian }}$}

Berdasarkan latar belakang masalah dan rumusan masalah yang ada, karakteristik masalah yang diteliti dalam penelitian ini dapat diklasifikasikan sebagai 
hyphotesis testing, yaitu suatu penelitian dimana hasilnya dijelaskan dengan pengujian hipotesis. Dalam hal ini tujuannya adalah menjelaskan pengaruh variabel-variabel profitabilitas (NPM dan ROE) dan leverage (DER dan DR) terhadap harga saham pada perusahaan Perbankan dan Asuransi di BEI. Penelitian ini merupakan penelitian empiris dengan menggunakan data sekunder. Artinya penelitian ini mendasarkan pada data sekunder yang diambil dan dikutip dari data yang sudah tersedia pada objek yang diteliti.

\section{Populasi dan Sampel}

Populasi dalam penelitian ini adalah perusahaan Perbankan dan Asuransi yang go public di Bursa Efek Indonesia pada periode 2010-2014. Penentuan sampel dalam penelitian ini menggunakan metode purposive sampling. Kriteria pengambilan sampel dalam penelitian ini:

- Perusahaan telah tercatat di BEI selama tahun 2010 - 2014 dan menerbitkan laporan keuangan secara periodic.

- Perusahaan memiliki beta positif atau sahamnya aktif diperdagangkan. Syarat ini ditetapkan untuk menghindari saham-saham yang likuiditasnya rendah.

Jenis dan Sumber Data

Data yang digunakan dalam penelitian ini adalah data sekunder yang diambil dari Indonesian Capital Market Directory (ICMD) dan Laporan Keuangan tahunan perusahaan di BEI yang meliputi laporan neraca, dan laporan laba-rugi pada tahun 2010 -2014, serta www.yahoofinance.com. Adapun jenis data yang digunakan dalam penelitian ini termasuk pooling data yang merupakan gabungan antara data time series dan cross section.

\section{Metode Analisis Data}

Metode ini bertujuan untuk menentukan pengaruh-pengaruh variabel-vriabel independen, yaitu NPM, ROE, DER, dan DR terhadap Cumulative Abnormal Retum (CAR) Saham. Model tersebut dapat dinyatakan sebagai berikut (Gujarati, 2006: 24):

$$
Y_{t}=b_{0}+b_{1} X_{1 t}+b_{2} X_{2 t}+b_{3} X_{3 t}+b_{4} X_{4 t}+e_{t}
$$

Dimana:

$$
\begin{array}{ll}
\mathrm{Y} & =\text { Cumulative Abnormal Return Saham } \\
\mathrm{b}_{0} & =\text { Konstanta } \\
\mathrm{X}_{1} & =\mathrm{NPM} ; \mathrm{X}_{2}=\mathrm{ROE} ; \mathrm{X}_{3}=\mathrm{DER} ; \mathrm{X}_{4}=\mathrm{DR} \\
\mathrm{e} & =\text { Tingkat kesalahan yang mungkin terjadi }
\end{array}
$$


$\mathrm{b}_{1}, \mathrm{~b}_{2}, \mathrm{~b}_{3}, \mathrm{~b}_{4} \quad=$ Koefisien regresi $\mathrm{X}_{1}, \mathrm{X}_{2}, \mathrm{X}_{3}, \mathrm{X}_{4}$

\section{Hasil dan Pembahasan}

\section{Statistik Deskriptif}

Variabel yang digunakan dalam penelitian ini adalah profitabilitas (net profit margin dan return on equity), leverage (debt equity ratio dan debt ratio), dan cumulative abnormal return tahun 2004-2010. Tabel 1 menyajikan statistik deskriptif untuk masingmasing variabel yang digunakan dalam penelitian ini.

Tabel 1. Statistik deskriptif variabel penelitian (dlm \%)

\begin{tabular}{lllll}
\hline Persh & Var & Min & Maks & Rata-Rata \\
\hline \multirow{4}{*}{ Perbankan } & $X_{1}$ & 0.240 & 16.640 & 5.610 \\
\cline { 2 - 5 } & $X_{2}$ & -142.480 & 43.830 & 12.602 \\
\cline { 2 - 5 } & $X_{3}$ & 0.430 & 15.420 & 7.983 \\
\cline { 2 - 5 }$X_{4}$ & 0.040 & 1.140 & 0.859 \\
\hline \multirow{3}{*}{ Asuransi } & $Y$ & -4.021 & 2.400 & -0.374 \\
\cline { 2 - 5 } & $X_{1}$ & 0.150 & 1.270 & 0.518 \\
\cline { 2 - 5 } & $X_{2}$ & -1.340 & 30.000 & 14.824 \\
\cline { 2 - 5 } & $X_{3}$ & 0.276 & 5.115 & 1.979 \\
\cline { 2 - 5 } & $Y$ & 0.220 & 0.850 & 0.583 \\
\hline
\end{tabular}

Sumber: diolah

Berdasarkan Tabel 1 dapat dilihat bahwa rata-rata net profit margin untuk perusahaan perbankan sebesar $5,610 \%$. Sedangkan rata-rata net profit margin pada perusahaan asuransi sebesar $0,518 \%$. Berdasarkan nilai tersebut, dapat dinyatakan bahwa perusahaan perbankan memiliki kemampuan operasi yang lebih baik dalam menghasilkan keuntungan. Hal ini bisa disebabkan bahwa perusahaan perbankan lebih baik efisien dalam mengeluarkan biaya-biaya sehubungan dengan kegiatan operasinya.

Rata-rata return on equity untuk perusahaan perbankan sebesar $12,602 \%$. Sedangkan rata-rata net profit margin pada perusahaan asuransi sebesar $14,824 \%$. Berdasarkan nilai tersebut, dapat dinyatakan bahwa perusahaan asuransi memiliki kemampuan yang lebih baik dalam menghasilkan keuntungan bagi pemegang saham preferen dan saham biasa. Hal ini bisa disebabkan bahwa perusahaan asuransi lebih baik dalam mengelola modal sendirinya untuk menghasilkan keuntungan bagi perusahaan. 
Rata-rata debt equity ratio untuk perusahaan perbankan sebesar 7,983\%. Sedangkan rata-rata debt equity ratio pada perusahaan asuransi sebesar 1,979\%. Berdasarkan nilai tersebut, dapat dinyatakan bahwa perusahaan perbankan maupun perusahaan asuransi memiliki nilai debt equity ratio yang positif yang mengindikasikan bahwa perusahaan mampu memenuhi kewajibannya dengan modal sendiri.

Rata-rata debt ratio untuk perusahaan perbankan sebesar 0,859\%. Sedangkan rata-rata debt ratio pada perusahaan asuransi sebesar 0,583\%. Berdasarkan nilai tersebut, dapat dinyatakan bahwa perusahaan perbankan maupun perusahaan asuransi memiliki nilai debt ratio yang positif yang mengindikasikan bahwa perusahaan menggunakan hutang untuk membiayai aktivanya.

Rata-rata cumulative abnormal return untuk perusahaan perbankan sebesar 0,374\%. Sedangkan rata-rata cumulative abnormal return pada perusahaan asuransi sebesar $0,221 \%$. Berdasarkan nilai tersebut, dapat dinyatakan bahwa perusahaan perbankan memiliki nilai cumulative abnormal return yang negatif yang mengindikasikan bahwa investor baik pada perusahaan perbankan tidak mendapatkan abnormal return, yang bisa disebabkan oleh adanya informasi yang sama yang diterima oleh setiap investor.

\section{Analisis Regresi Linier Berganda}

Pengujian regresi linear berganda berguna untuk mengetahui tingkat pengaruh dari profitabilitas (net profit margin dan return on equity) dan leverage (debt equity ratio dan debt ratio) terhadap cumulative abnormal return. Berdasarkan metode analisis yang dikemukakan sebelumnya, berikut ini akan ditampilkan hasil estimasi regresi yaitu:

Tabel 2. Hasil Analisis Regresi Linier Berganda Perbankan

\begin{tabular}{lllll}
\hline Variabel & Prediksi & Koef. & thitung & Sig. \\
\hline \multicolumn{2}{l}{ Konstanta } & -4.062 & -1.180 & 0.240 \\
\hline$X_{1}+$ & 0.049 & 0.548 & 0.585 \\
\hline$X_{2}+$ & 0.045 & 3.308 & 0.001 \\
\hline$X_{3}-$ & -0.002 & -0.023 & 0.982 \\
\hline$X_{4}-$ & 3.222 & 0.752 & 0.454 \\
\hline$R$ R Square) & & & $0.335(0.113)$ \\
Standar Error & & & 0,407 \\
Fhitung (sig) & & & $3.804(0.006)$ \\
Fsig & & & 145 \\
\hline
\end{tabular}

Sumber: diolah 
Berdasarkan hasil analisis didapat persamaan regresi sebagai berikut:

$$
Y=-4,062+0,049 X_{1}+0,045 X_{2}-0,002 X_{3}+3,222 X_{4}+e
$$

Dalam persamaan tersebut dapat diketahui bahwa variabel debt equity ratio, mempunyai pengaruh yang negatif terhadap cumulative abnormal return, sedangkan variabel net profit margin, return on equity, dan debt ratio mempunyai pengaruh positif terhadap cumulative abnormal return.

Tabel 3. Hasil Analisis Regresi Linier Berganda pada Perusahaan Asuransi

\begin{tabular}{|c|c|c|c|c|}
\hline $\begin{array}{l}\text { Varia } \\
\text { bel }\end{array}$ & Prediksi & Koef. & thitung & Sig. \\
\hline \multicolumn{5}{|c|}{ Kons } \\
\hline $\mathrm{X}_{1}$ & + & 0.099 & 0.105 & 0.917 \\
\hline $\mathrm{X}_{2}$ & + & 0.098 & 2.876 & 0.006 \\
\hline$X_{3}$ & - & -0.152 & -0.443 & 0.660 \\
\hline $\mathrm{X}_{4}$ & - & -3.223 & -1.103 & 0.276 \\
\hline $\mathrm{R}(\mathrm{R}$ & Square) & & & $0.541(0.293)$ \\
\hline Stanc & dar Error & & & 1.431 \\
\hline Fhitu & ng (sig) & & & $4.655(0.003)$ \\
\hline Fsig & & & & 50 \\
\hline
\end{tabular}

Sumber: Data Diolah

Berdasarkan hasil analisis didapat persamaan regresi sebagai berikut:

$$
Y=0,904+0,099 X_{1}+0,098 X_{2}-0,152 X_{3}-3,223 X_{4}+e
$$

Dari persamaan tersebut dapat diketahui bahwa variabel debt equity ratio dan debt ratio mempunyai pengaruh yang negatif terhadap cumulative abnormal return, sedangkan variabel net profit margin dan return on equity mempunyai pengaruh positif terhadap cumulative abnormal return.

\section{Pengujian Hipotesis}

- Ujit

Berdasarkan Tabel 2 untuk pengujian perusahaan perbankan terlihat bahwa nilai probabilitas return on equity lebih kecil daripada probabilitas yang disyaratkan (5\%), sedangkan net profit margin, debt equity ratio, dan debt ratio memiliki probabilitas lebih besar dari 5\%. Dari hasil uji t ditunjukkan bahwa ada pengaruh yang signifikan return on equity terhadap cumulative abnormal return, sedangkan net profit margin, debt equity ratio, dan debt ratio tidak memiliki pengaruh yang signifikan terhadap cumulative abnormal return. Hal ini berarti secara parsial terbukti bahwa return on equity berpengaruh terhadap cumulative abnormal return, sehingga hipotesis yang diajukan 
yaitu $\mathrm{H}_{2}$ diterima. Sedangkan net profit margin, debt equity ratio, dan debt ratio secara parsial tidak berpengaruh terhadap cumulative abnormal return $\left(\mathrm{H}_{1}, \mathrm{H}_{3}\right.$, dan $\mathrm{H}_{4}$ ditolak). Berdasarkan hasil tersebut dapat dinyatakan bahwa ROE berpengaruh positif terhadap abnormal return saham pada perusahaan perbankan di BEI.

Berdasarkan Tabel 3 untuk pengujian perusahaan asuransi terlihat bahwa nilai probabilitas return on equity lebih kecil daripada probabilitas yang disyaratkan (5\%), sedangkan net profit margin, debt equity ratio, dan debt ratio memiliki probabilitas lebih besar dari 5\%. Dari hasil uji t ditunjukkan bahwa ada pengaruh yang signifikan return on equity terhadap cumulative abnormal return, sedangkan net profit margin, debt equity ratio, dan debt ratio tidak memiliki pengaruh yang signifikan terhadap cumulative abnormal return. Hal ini berarti secara parsial terbukti bahwa return on equity berpengaruh terhadap cumulative abnormal return, sehingga hipotesis yang diajukan yaitu $\mathrm{H}_{2}$ diterima. Sedangkan net profit margin, debt equity ratio, dan debt ratio secara parsial tidak berpengaruh terhadap cumulative abnormal return $\left(\mathrm{H}_{1}, \mathrm{H}_{3}\right.$, dan $\mathrm{H}_{4}$ ditolak). Berdasarkan hasil tersebut dapat dinyatakan bahwa ROE berpengaruh positif terhadap abnormal return saham pada perusahaan Asuransi di BEl.

- Uji Chow

Hasil Uji Chow secara ringkas dapat dilihat pada Tabel 4.

Tabel 4. Ringkasan Hasil Uji Chow

\begin{tabular}{llll}
\hline Pengujian & RSS & $\mathrm{N}$ & $\mathrm{k}$ \\
\hline Perbanka & & & \\
$\mathrm{n}$ & 245.649 & 125 & 4 \\
\hline Asuransi & 85.579 & 50 & 4 \\
\hline Total & 342.616 & 175 & 4 \\
\hline
\end{tabular}

Sumber: Data Diolah

Dari ringkasan hasil uji Chow pada Tabel 4 selanjutnya dapat dihitung nilai $\mathrm{F}$ sebagai berikut: Hasil perhitungan uji Chow memperoleh nilai Fnitung sebesar 3,725, sedangkan nilai Ftabel pada df $=4$ dan 167 adalah sebesar 2,43. Oleh karena nilai F Fitung lebih besar dari $F_{\text {tabel }}$ maka dapat disimpulkan bahwa terdapat perbedaan yang signifikan pengaruh profitabilitas dan leverage terhadap cumulative abnormal return antara perusahaan perbankan dan perusahaan asuransi di Bursa Efek Indonesia. Berdasarkan hasil tersebut, hipotesis yang menyatakan bahwa ada perbedaan pengaruh profitabilitas (ROE dan NPM) dan leverage (DER dan DR) terhadap abnormal return saham pada perusahaan Perbankan dan Asuransi di BEl terbukti kebenarannya ( $\mathrm{H}_{5}$ diterima). 


\section{$\underline{\text { Pengaruh Net Profit Margin terhadap Cumulative Abnormal Return }}$}

Hasil penelitian menunjukkan bahwa net profit margin berpengaruh positif namun tidak signifikan terhadap cumulative abnormal return baik pada perusahaan perbankan maupun perusahaan asuransi. Net profit margin biasa juga disebut rentabilitas ekonomi yang merupakan ukuran kemampuan perusahaan dalam menghasilkan keuntungan bersih. Rasio ini merupakan perbandingan antara laba bersih setelah pajak dengan penjualan (pendapatan). Semakin tinggi nilai rasio net profit margin, menunjukkan semakin baik kemampuan perusahaan dalam memanajemen asetnya untuk menghasilkan keuntungan dan semakin efisien perusahaan dalam mengeluarkan biaya-biaya sehubungan dengan kegiatan operasinya.

Arah hubungan yang positif antara net profit margin dan cumulative abnormal return menunjukkan bahwa semakin tinggi rasio profitabilitas, dalam hal ini net profit margin, maka tingkat keuntungan yang diperoleh investor juga semakin tinggi. Hal ini bisa disebabkan bahwa kemampuan perusahaan dalam memanakemen asetnya untuk menghasilkan keuntungan yang semakin baik tentunya merupakan berita baik (good news) bagi investor untuk menginvestasikan danya pada perusahaan yang memiliki kemampuan menghasilkan keuntungan. Pasar saham biasanya cenderung merespon positif perusahaan yang mencatatkan keuntungan dalam laporan keungannya. Diperolehnya hasil yang tidak signifikan pada pengujian perusahan perbankan dan asuransi menunjukkan bahwa investor kurang mempertimbangkan pertumbuhan keuntungan dalam mengambil keputusan investasinya. Kemungkinan lain yang terjadi adalah investor dalam melakukan investasi tidak mendasarkan pada faktor fundamental, sehingga cumulative abnormal return yang terjadi lebih banyak dipengaruhi oleh faktor di luar akuntansi. Temuan penelitian ini tidak sesuai dan tidak mendukung hasil penelitian dari Hutami (2012) yang menyatakan bahwa net profit margin berpengaruh signifikan terhadap harga saham.

\section{Pengaruh Return on Equity terhadap Cumulative Abnormal Return}

Hasil penelitian menunjukkan bahwa return on equity berpengaruh positif dan signifikan terhadap cumulative abnormal return baik pada perusahaan perbankan maupun perusahaan asuransi. Return on Equity sering disebut rate of return net worth. ROE sering disebut rentabilitas modal sendiri. Rasio ini merupakan perbandingan antara laba bersih setelah pajak dengan modal sendiri. Hasil rasio ini dijadikan 
gambaran besarnya kembalian atas modal yang ditanamkan atau kemampuan modal sendiri untuk menghasilkan keuntungan bagi pemegang saham preferen dan saham biasa. Selain itu juga dijadikan dasar pertimbangan bagi kreditur dalam memberikan pinjaman terhadap perusahaan.

Menurut Husnan (2004: 74) Return on Equitymerupakan rasio untuk mengukur seberapa banyak laba yang menjadi hak pemilik modal sendiri. Menurut Lestari, Lutfi dan Syahyunan (2007: 5), ROE merupakan rasio penting bagi para pemilik dan pemegang saham karena rasio tersebut menunjukkan kemampuan perusahaan dalam mengelola modal dari pemegang saham untuk mendapatkan laba bersih. Perusahaan yang memiliki Return on Equity yang rendah atau bahkan negatif akan terklasifikasikan sebagai perusahaan yang kurang baik dalam menghasilkan laba yang menjadi hak pemegang saham. Hal ini ditambahkan dengan teori yang diungkapkan oleh Chrisna (2011: 34) bahwa kenaikan Return on Equity biasanya diikuti oleh kenaikan harga saham perusahaan tersebut. Semakin tinggi ROE berarti semakin baik kinerja perusahaan dalam mengelola modalnya untuk menghasilkan keuntungan bagi pemegang saham. Dapat dikatakan bahwa perusahaan tersebut dapat menggunakan modal dari pemegang saham secara efektif dan efisien untuk memperoleh laba. Dengan adanya peningkatan laba bersih maka nilai ROE akan meningkat pula sehingga para investor tertarik untuk membeli saham tersebut maka harga saham perusahaan tersebut akan mengalami kenaikan. Teori tersebut semakin memperkuat hasil penelitian ini, yaitu Return on Equity berpengaruh positif dan signifikan terhadap cumulative abnormal return saham perusahaan perbankan dan asuransi yang tercatat di Bursa Efek Indonesia.

Pengaruh Debt Equity Ratio terhadap Cumulative Abnormal Return

Hasil penelitian menunjukkan bahwa debt equity ratio, mempunyai pengaruh yang negatif terhadap cumulative abnormal return pada perusahaan perbankan dan asuransi. Debt equity ratio berfungsi untuk mengetahui proporsi modal sendiri dibandingkan dengan hutang. Dengan kata lain, menunjukkan kemampuan modal sendiri perusahaan yang dapat memenuhi seluruh kewajibannya. Semakin tinggi nilai rasio debt equity ratio, berarti semakin tinggi penggunaan hutang oleh perusahaan yang berarti pula risiko perusahaan.

Dengan proporsi hutang yang semakin besar, akan menimbulkan risiko yang besar dan para investor akan menetapkan expected return lebih besar lagi terhadap 
setiap rupiah yang ditanam di perusahaan tersebut (premium financial risk). Sehingga pada akhirnya nilai perusahaan akan cenderung turun. Dalam kondisi pasar yang bagus, penambahan hutang memang akan meningkatkan keuntungan perusahaan. Namun apabila kondisi pasar buruk seperti kondisi krisis ekonomi dan moneter, hanya akan membuat pemanfaatan hutang berakibat pada menurunnya profitabilitas perusahaan. Hal ini dikarenakan return yang diperoleh lebih kecil daripada biaya yang harus dikeluarkan untuk mendanai bunga hutang.

\section{$\underline{\text { Pengaruh Debt Ratio terhadap Cumulative Abnormal Return }}$}

Hasil penelitian menunjukkan bahwa debt ratio, mempunyai pengaruh yang positif terhadap cumulative abnormal return pada perusahaan perbankan. Sedangkan pada perusahaan asuransi, debt ratio mempunyai pengaruh negatif terhadap cumulative abnormal return. Debt ratio berfungsi untuk memperlihatkan proporsi antara kewajiban yang dimiliki dengan seluruh kekayaan yang dimiliki perusahaan. Dengan kata lain dapat mengetahui berapa besar aktiva untuk membiayai hutang. Semakin tinggi nilai rasio debt ratio, berarti semakin tinggi penggunaan hutang oleh perusahaan yang berarti pula risiko perusahaan.

Sama halnya dengan debt equity ratio, tingginya nilai debt ratio juga menggambarkan tingginya proporsi hutang perusahaan. Dengan proporsi hutang yang semakin besar, akan menimbulkan risiko yang besar dan para investor akan menetapkan expected return lebih besar lagi terhadap setiap rupiah yang ditanam di perusahaan tersebut (premium financial risk). Sehingga pada akhirnya nilai perusahaan akan cenderung turun. Dalam kondisi pasar yang bagus, penambahan hutang memang akan meningkatkan keuntungan perusahaan. Namun apabila kondisi pasar buruk seperti kondisi krisis ekonomi dan moneter, hanya akan membuat pemanfaatan hutang berakibat pada menurunnya profitabilitas perusahaan. Hal ini dikarenakan return yang diperoleh lebih kecil daripada biaya yang harus dikeluarkan untuk mendanai bunga hutang.

Dalam penelitian ini perlu dicermati beberapa hal sehubungan dengan hasil penelitian, terutama yang berkenaan dengan arah koefisien yang berbeda, pengaruh yang tidak signifikan serta rendahnya koefisien deteminasi. Hal-hal tersebut antara lain disebakan adanya keterbatasan penelitian sebagai berikut.

- Penelitian ini terbatas pada perbankan dan asuransi yang tercatat di BEI dengan jumlah sampel sebanyak 29 perusahaan perbankan dan 10 perusahaan asuransi 
sehingga hasil dari penelitian berbeda dengan penelitian sebelumnya yang mempunyai populasi berbeda.

- Rentang waktu dalam penelitian ini hanya lima tahun, yaitu 2010 - 2014.

- Kondisi perekonomian makro Indonesia selama periode penelitian dinilai juga memengaruhi hasil penelitian diantaranya pada periode tersebut ekonomi Indonesia masih berada pada kondisi krisis yang ditandai dengan turunnya nilai mata uang rupiah dan berlanjut pada terjadinya inflasi. Ditambah lagi situasi politik Indonesia pada periode tersebut sangat tidak stabil. Kondisi seperti ini tentunya sangat memengaruhi pasar modal Indonesia, risiko pasar semakin meningkat dan perhatian investor tidak hanya akan tertuju pada faktor fundamental perusahaan, tetapi juga pada faktor political risk.

\section{Kesimpulan}

Dari hasil penelitian yang dilakukan pada 39 perusahaan sampel selama periode tahun 2010 sampai dengan 2014 dapat diperoleh kesimpulan sebagai berikut: (1) NPM berpengaruh positif namun tidak signifikan terhadap abnormal return saham pada perusahaan Perbankan dan Asuransi di BEI. ROE berpengaruh positif dan signifikan terhadap abnormal return saham pada perusahaan Perbankan dan Asuransi di BEI. DER berpengaruh negatif namun tidak signifikan terhadap abnormal return saham pada perusahaan Perbankan dan Asuransi di BEI. DR berpengaruh positif namun tidak signifikan terhadap abnormal return saham pada perusahaan Perbankan di BEI. Sedangkan pada perusahaan Asuransi di BEI, DR berpengaruh negatif namun tidak signifikan terhadap abnormal return saham; dan (2) Ada perbedaan pengaruh profitabilitas (NPM dan ROE) dan leverage (DER dan DR) terhadap abnormal return saham pada perusahaan Perbankan dan Asuransi di BEl.

\section{Saran}

Berdasarkan keterbatasan dan kesimpulan, dapat diajukan beberapa saran yaitu sebagai berikut: (1) Bagi investor, diharapkan tidak hanya menjadikan harga saham sebabagai acuan dalam menanamkan modalnya tetapi juga memperhatikan kinerja perusahaan sebagaimana tercermin dalam laporan keuangannya khususnya Return on Equity, karena dari Return on Equity bisa diketahui besarnya tingkat pengembalian modal yang diterima oleh investor; dan (2) Untuk penelitian yang akan datang dengan tema sejenis diharapkan untuk dapat menambahkan objek penelitian 
(sektor industri lain) sehingga hasil temuannya lebih mewakili perilaku pasar modal yang lebih luas, serta menambah variabel yang digunakan sehingga diperoleh hasil yang lebih baik dalam menjelaskan abnormal return saham seperti tingkat inflasi, tingkat suku bunga, pertumbuhan ekonomi, dan lain-lain.

\section{Daftar Referensi}

Ali, Masyhud. 2006. Manajemen Risiko. Jakarta: Raja Grafindo Persada.

Brigham, Eugene F. 2006. Financial Management: Theory and Practice. $9^{\text {th }}$ edition. Florida: Harcourt College Pubilsher.

Brigham, Eugene F. dan Joel F. Houston. 2006. Dasar-Dasar Manajemen Keuangan. Jakarta: Salemba Empat.

Cooper, Donal R. dan Emory, William. 1999. Metode Penelitian Bisnis. alih bahasa Widyono Soecipto dan Uka Wikarya, Jilid 11, Jakarta: Erlangga.

Djarwanto. 2001. Pokok-pokok Analisa Laporan Keuangan. Yogyakarta: BPFEYogyakarta.

Ghozali, Imam. 2006. Aplikasi Analisis Multivariate dengan Program SPSS. Semarang: Universitas Diponegoro.

Gujarati, Damodar. 2006. Ekonometrika Dasar. Jakarta: Erlangga.

Gumanti, Tatang Ary. 2007. Manajemen Investasi Konsep, Teori, dan Aplikasi. Jember: Center for Society Studies.

Hartono, Jogiyanto. 2007. Teori Portofolio dan Analisis Investasi, Edisi 5. Yogyakarta: BPFE.

Helfert, Erich A. 2003. Technique of Financial Analysis, a guide to value creation, $11^{\text {th }}$ edition, Mc Graw. Hill-Irwin, North America.

Hempel, George H., Donald G. Simonson, and Alan B. Coleman. 1998. Bank Management. United States of America: John Wiley and Sons Inc.

Horne, James C. Van dan John M. Wachowicz JR, 2005. Fundamental Of Financial Management, Prinsip-prinsip Manajemen Keuangan, Buku satu, edisi keduabelas, alih bahasa oleh Dewi Fitriasari dan Dony Arnos Kwary, Jakarta: PT Salemba Empat.

Husnan, Suad. 2008. Manajemen Keuangan : Teori Dan Penerapan. Buku 1 Edisi-4. Yogyakarta: BPFE.

Munawir, S. 2005. Analisis Laporan Keuangan. Yogyakarta: Liberty Yogyakarta.

Natarsyah, Syahib. 2000. Analisis Pengaruh Beberapa Faktor Fundamental dan Resiko Sistematik terhadap Harga Saham: Kasus Barang Konsumsi yang Go- 
Public di Pasar Modal Indonesia. Jurnal Ekonomi Bisnis Indonesia 15 (3): 294 1312.

Riyanto, Bambang. 2008. Dasar-dasar Pembelanjaan Perusahaan. Yogyakarta: BPFE.

Santoso, Singgih. 2010. Statistik Parametrik: Konsep dan Aplikasi dengan SPSS. Jakarta: PT. Exel Media Komputindo.

Sartono, Agus. 2010. Manajemen Keuangan (Teori dan Aplikasi). Yogyakarta: BPFEUGM.

Sugiyono. 2005. Metode Penelitian Bisnis. edisi pertama. cetakan kedelapan. Bandung: CV Alfabeta.

Syamsudin, Lukman. 2004. Manajemen Keuangan Perusahaan: Konsep Aplikasi dalam Perencanaan dan Pengambilan Keputusan. Edisi Baru. Jakarta: PT. Raja Grafindo Perkasa.

Umar, Husein. 2003. Metode Riset Akuntansi Terapan. edisi pertama. Jakarta: Ghalia Indonesia.

Van Horne, James dan John M, Wachowicz, Jr, 2006. Prinsip Prinsip Manajemen Keuangan. Terjemahan Heru Sutejo, Buku Satu, Edisi Kesembilan, Jakarta: Salemba Empat.

Weston, J. Fred dan Copeland, Thomas E. 2008. Manajemen Keuangan. Alih Bahasa: Jaka Wasana dan Kirboandoko. Jilid II. Jakarta: Erlangga.

Weston, J. Fred. 2004. Dasar-Dasar Manajemen Keuangan. Jilid 2, Edisi Kesembilan. Jakarta: Salemba Empat.

Weston, J.F dan Brigham E.F. 2005. Manajemen Keuangan. Jilid I. alih Bahasa: A.Q Khalid. Jakarta: Erlangga. 